\title{
Genetic analysis of the effect of zinc deficiency on Arabidopsis growth and mineral concentrations
}

\author{
Artak Ghandilyan - Umit Baris Kutman • \\ Bahar Yildiz Kutman • Ismail Cakmak • \\ Mark G. M. Aarts
}

Received: 1 March 2012 / Accepted: 11 June 2012 / Published online: 23 June 2012

(C) The Author(s) 2012. This article is published with open access at Springerlink.com

\begin{abstract}
Aims Zinc deficiency is a common micronutrient deficiency in plants growing in many different regions of the world and is associated with disturbances in uptake and accumulation of mineral nutrients. Despite many published data on physiological factors affecting ion accumulation in $\mathrm{Zn}$ deficient plants, there is very little information about the genetic factors underlying this. We aim to identify genetic loci involved in mineral accumulation and plant performance under $\mathrm{Zn}$ deficiency.

Methods Genetic loci were identified using the genetically segregating Ler $\times$ Cvi recombinant inbred line (RIL) population grown under $\mathrm{Zn}$ deficient conditions. Lines were analysed for the concentrations of $\mathrm{Zn}, \mathrm{Fe}$, $\mathrm{Mn}, \mathrm{K}, \mathrm{Ca}, \mathrm{Mg}, \mathrm{P}, \mathrm{Cu}, \mathrm{S}$ and $\mathrm{Al}$ in shoot dry matter. The same was done for the same lines grown under $\mathrm{Zn}$ sufficient conditions.

Results We found considerable heritable variation for most mineral concentrations. In general, there was a
\end{abstract}

Responsible Editor: Michael A. Grusak.

A. Ghandilyan • M. G. M. Aarts $(\bowtie)$

Laboratory of Genetics, Wageningen University,

Droevendaalsesteeg 1,

6708 Wageningen, The Netherlands

e-mail: mark.aarts@wur.nl

U. B. Kutman • B. Y. Kutman • I. Cakmak

Faculty of Engineering and Natural Sciences,

Sabanci University,

34956 Istanbul, Turkey positive correlation between mineral concentrations. For Zn only condition-dependent QTLs were identified, while for most other mineral concentrations both condition-dependent and -independent QTLs were identified. Several QTLs co-localize, including colocalization to loci controlling shoot biomass and to mineral concentration loci found previously in this and other RIL populations.

Conclusions There are different genetic loci controlling $\mathrm{Zn}$ accumulation under deficient and sufficient $\mathrm{Zn}$ supply. Only for few minerals, their accumulation is controlled by Zn-supply-specific loci.

Keywords Mineral deficiency $\cdot$ QTL $\cdot$ Recombinant inbred line $\cdot$ Zinc $\cdot$ Arabidopsis thaliana

\section{Introduction}

Plants require essential minerals, including zinc ( $\mathrm{Zn})$, and are at the same time an important dietary source of essential minerals for humans. Zinc deficiency is a common micronutrient deficiency in plants growing in different regions of the world including India, China, Australia, Pakistan and Turkey (Alloway 2008; Cakmak 2000, 2008; Sillanpaeae 1982). Turkey is a major wheat-producing country, where nearly $45 \%$ of the production area is located on highly calcareous soils in Central Anatolia (Cakmak et al. 1996). In this region, $\mathrm{Zn}$ deficiency represents a critical plant nutrition problem, substantially limiting wheat production 
(Cakmak et al. 1999a; Cakmak et al. 1996). Soil Zn deficiency in general affects both the nutritional quality (e.g. low $\mathrm{Zn}$ contents of seeds and grains) and the yield of food crops. It is therefore not surprising that soil $\mathrm{Zn}$ deficiency and human $\mathrm{Zn}$ deficiency are often closely associated (Cakmak 2008). Understanding the genetics of how plants deal with $\mathrm{Zn}$ deficiency, comprising the acquisition of $\mathrm{Zn}$ from the soil, distribution of $\mathrm{Zn}$ throughout the plant and storage of $\mathrm{Zn}$, under Zn-limited conditions, while maintaining homeostasis of $\mathrm{Zn}$ and other mineral nutrients, is an important issue for breeding for $\mathrm{Zn}$-efficient crops.

Zinc efficiency is defined as the ability of a plant genotype to maintain growth and yield well on a $\mathrm{Zn}$ limited soil (Graham 1984). Different mechanisms are involved in $\mathrm{Zn}$ efficiency in plants, including enhanced $\mathrm{Zn}$ bioavailability in the rhizosphere by the release of root exudates, increased root $\mathrm{Zn}$ uptake and better internal $\mathrm{Zn}$ utilization (Cakmak et al. 1999b; Rengel et al. 1999). While differences in $\mathrm{Zn}$ efficiency have been determined for several crop species, there are relatively few studies assessing the genetic basis of these differences among genotypes of the same species in $\mathrm{Zn}$ deficient and -sufficient conditions (Genc et al. 2009; Wissuwa et al. 2006; $\mathrm{Wu}$ et al. 2007). A firm understanding of the genetic regulation of mineral homeostasis is also required to accelerate breeding for crop bio-fortification, which is a method of breeding crops for increased nutritional value (www.harvestplus.org) (Bouis 2002).

Quantitative trait locus (QTL) analysis is a powerful method to identify the genetic factors involved in controlling a trait (Alonso-Blanco et al. 2009). It provides information on the chromosomal location of the target loci without prior knowledge of the genes related to the trait, which can be conveniently used to identify QTLs affecting mineral homeostasis in crops (Ghandilyan et al. 2006). The A. thaliana Ler $\times$ Cvi Recombinant Inbred Line (RIL) immortal mapping population (Alonso-Blanco et al. 1998), derived from a cross between the Landsberg erecta (Ler) lab strain and the Cape Verde Islands (Cvi) accession, has been used extensively to study the genetic basis of multiple traits in Arabidopsis (recently reviewed by (Alonso-Blanco et al. 2009)) including mineral content in seeds (Vreugdenhil et al. 2004; Waters and Grusak 2008). QTL analyses of mineral concentrations in seeds, rosettes and roots were conducted in Arabidopsis Ler $\times$ Kond, Ler $\times$ An-1 and Ler $\times$ Eri populations grown under various conditions (Ghandilyan et al. 2009b).

In order to identify genetic factors involved in mineral homeostasis of Arabidopsis under natural $\mathrm{Zn}$ deficient conditions, the Ler $\times$ Cvi RIL population was grown on $\mathrm{Zn}$ deficient soil from Central Anatolia, supplemented with low or adequate $\mathrm{Zn}$ to complement the otherwise extreme deficiency, and mineral QTLs were determined.

\section{Materials and methods}

Plant material and growing conditions

Arabidopsis thaliana lab strain Landsberg erecta (Ler, N20; Nottingham Arabidopsis Stock Centre, www.arabidopsis.info) and accession Cape Verde Islands (Cvi, N8580; Nottingham Arabidopsis Stock Centre, www.arabidopsis.info), and the recombinant inbred line (RIL) population derived from the cross between these two accessions (RIL Ler $\times$ Cvi) (Alonso-Blanco et al. 1998), were used for the experiments. The parents and population were grown on naturally $\mathrm{Zn}$ deficient soil, with minor or adequate $\mathrm{Zn}$ supplementation, in a climate-controlled greenhouse. The $\mathrm{Zn}$ deficient and nutrient-poor soil originated from Eskisehir, Central Anatolia, Turkey. This was an alkaline $\left(\mathrm{pH} 8.1\right.$ in $\left.\mathrm{dH}_{2} \mathrm{O}\right)$ and calcareous $\left(12 \% \mathrm{CaCO}_{3}\right)$ soil with a low organic matter content $(1.1 \%)$. The diethylenetriamine pentaacetic acid (DTPA)-extractable mineral concentrations were $0.13 \mathrm{mg} \cdot \mathrm{kg}^{-1}$ for $\mathrm{Zn}$, $1.84 \mathrm{mg} \cdot \mathrm{kg}^{-1}$ for $\mathrm{Fe}, 4.91 \mathrm{mg} \cdot \mathrm{kg}^{-1}$ for $\mathrm{Mn}$, and $0.89 \mathrm{mg} . \mathrm{kg}^{-1}$ for $\mathrm{Cu}$. The $\mathrm{NaHCO}_{3}$-extractable P concentration was $3.63 \mathrm{mg} \cdot \mathrm{kg}^{-1}$, and the ammonium acetate-extractable concentrations of $\mathrm{K}$ and $\mathrm{Mg}$ were $478 \mathrm{mg} . \mathrm{kg}^{-1}$ and $424 \mathrm{mg} \cdot \mathrm{kg}^{-1}$, respectively.

After three-day stratification at $5{ }^{\circ} \mathrm{C}$, imbibed seeds were directly sown on to the prepared soil. The experiment was designed as a three-pot-replicate experiment in which each pot contained five plants. Replications were randomized within the plot. The soil was amended with essential nutrients prior to the sowing of the seeds: $200 \mathrm{mg} / \mathrm{kg} \mathrm{N}$ as calcium nitrate $\left[\mathrm{Ca}\left(\mathrm{NO}_{3}\right)_{2}\right], 100 \mathrm{mg} / \mathrm{kg}$ $\mathrm{P}$ as potassium di-hydrogen phosphate $\left(\mathrm{KH}_{2} \mathrm{PO}_{4}\right)$, $25 \mathrm{mg} / \mathrm{kg} \mathrm{S}$ as potassium sulfate $\left(\mathrm{K}_{2} \mathrm{SO}_{4}\right)$ and $3 \mathrm{mg} / \mathrm{kg}$ $\mathrm{Fe}$ as Fe-EDTA. Pots were supplied separately with $\mathrm{Zn}$ $\left(\mathrm{ZnSO}_{4}\right)$ as follows: $0.25 \mathrm{mg} \mathrm{Zn} / \mathrm{kg}$ soil for low $\mathrm{Zn}$ conditions ( $\mathrm{Zn}$ deficient) and $3 \mathrm{mg} \mathrm{Zn} / \mathrm{kg}$ soil for 
adequate $\mathrm{Zn}$ conditions ( $\mathrm{Zn}$ sufficient). Each pot contained $300 \mathrm{~g}$ of the fertilized soil. The soil surface of each pot was covered with perforated black nylon sheets. Each nylon sheet had five holes, uniformly dispersed. Several stratified and imbibed seeds were sown into each hole. The covers were used in order to reduce evaporative water loss from the soil and minimize soil contamination on plant shoots. The pots were placed in trays and watered from the bottom.

At harvesting time, the whole shoots, including the bolts if plants were bolting at the time of harvest were harvested and dried. Plant samples have been analyzed for mineral nutrients reported by inductively coupled plasma optical emission spectrometer (ICP-OES; Vista-Pro Axial; Varian Pty Ltd, Mulgrave, Australia) after their acid digestion in a closed-vessel microwave system. The details of the acid digestion and other steps are described by Aciksoz et al. (2011)

The $\mathrm{Zn}$ deficiency tolerance index (\%) was determined by using the following equation: (shoot dry weight under $\mathrm{Zn}$ deficient conditions/shoot dry weight under $\mathrm{Zn}$ sufficient conditions) $* 100$. Zinc efficiency was calculated using the following equation: shoot $\mathrm{Zn}$ concentration under $\mathrm{Zn}$ deficiency growth conditions/ shoot $\mathrm{Zn}$ concentration under $\mathrm{Zn}$ sufficient growth conditions. So-called KRAT $([\underline{\mathrm{K}}] /([\mathrm{Ca}]+[\mathrm{Mg}] \underline{\text { Ratio }})$ values were determined according to Larson and Mayland (2007). These are important for grazing animals, which stand the risk of grass tetany or hypomagnesaemia with KRAT values over 2.2. See Table 1 for abbreviations of all investigated traits.

\section{Statistical tests and QTL mapping}

For all statistical analyses, the statistical package SPSS version 15.0 was used. Differences in mean trait values of the genotypes were analysed by Univariate Analysis of Variance using the Dunnett's pairwise multiple comparison t-tests in the General Linear model module of the package. For each analysis, trait values were used as dependent variables, and genotypes were used as fixed factors. Two-sided tests were performed with a significance threshold level of 0.05 . Independent samples $t$-test of the package was used to determine mean differences between two individual lines. Correlation analyses were performed by calculating the Pearson or Spearman correlation coefficients.

The QTL mapping was performed using the computer program MapQTL version 5.0, which is based on composite interval mapping (http://www.kyazma.nl). LOD score thresholds distinguishing relevant QTLs are based on 1,000 permutation tests. Epistatic or QTL $\times$ QTL interactions occur when either the effect of one QTL is dependent on the presence of an allele at another locus or when each locus by itself appears to have no effect on the trait, yet when two loci are considered together there is an effect. A complete pairwise search for epistatic interactions for each trait ( $P<0.001$, determined by Monte Carlo simulations) was done using the EPISTAT statistical package (Chase et al. 1997).

\section{Results}

Variations in plant mineral concentrations

Shoot $\mathrm{Zn}, \mathrm{Fe}, \mathrm{Mn}, \mathrm{K}, \mathrm{Ca}, \mathrm{Mg}, \mathrm{P}, \mathrm{Cu}, \mathrm{S}$ and $\mathrm{Al}$ concentrations differed considerably between the RILs when grown on $\mathrm{Zn}$ deficient or $\mathrm{Zn}$ sufficient soil (Fig. 1). Shoot mineral concentrations varied 2.3- to 4.8-fold under $\mathrm{Zn}$ deficiency and 2.4- to 5.6-fold under $\mathrm{Zn}$ sufficiency (Table 2). As expected, shoot $\mathrm{Zn}$ concentrations were significantly lower under $\mathrm{Zn}$ deficiency when compared to the $\mathrm{Zn}$ sufficient conditions, while the concentrations of $\mathrm{Mn}, \mathrm{Ca}, \mathrm{Mg}$ were significantly higher under Zn deficiency. Zinc availability in the growth medium clearly affected the $\mathrm{Zn}$ status, but it did not significantly affect the Fe concentration (Fig. 2), even though $\mathrm{Zn}$ and Fe homeostasis are partly using similar transporters.

The fold difference for $\mathrm{Zn}$, i.e. the concentration of $\mathrm{Zn}$ in the RIL with the highest concentration divided by concentration of $\mathrm{Zn}$ in the RIL with lowest $\mathrm{Zn}$ concentration, was higher under $\mathrm{Zn}$ deficiency (3.1) than under $\mathrm{Zn}$ sufficiency (2.5). For Fe, the fold difference was higher at sufficient $\mathrm{Zn}$ (5.6) compared to deficient $\mathrm{Zn}$ (3.4). These observations that mineral concentrations and fold differences differ between both $\mathrm{Zn}$ supply conditions, implies that there will be genetic variation for mineral concentration, which depends on genotype-environment interactions.

\section{Correlation between traits}

Positive correlations were found for all shoot mineral concentrations, except for $\mathrm{Zn}$, when comparing $\mathrm{Zn}$ deficient and sufficient conditions (Table 3). 
Table 1 Abbreviations of the investigated traits

\begin{tabular}{|c|c|}
\hline Trait & Explanation \\
\hline Znd & shoot $\mathrm{Zn}$ concentrations under $\mathrm{Zn}$ deficiency conditions (ppm) \\
\hline Znc & shoot $\mathrm{Zn}$ concentrations under $\mathrm{Zn}$ sufficiency conditions (ppm) \\
\hline Znef & $\begin{array}{l}\text { shoot } \mathrm{Zn} \text { concentrations under } \mathrm{Zn} \text { deficiency conditions divided by shoot } \mathrm{Zn} \\
\text { concentrations under } \mathrm{Zn} \text { sufficiency conditions }\end{array}$ \\
\hline Fed & shoot Fe concentrations under Zn deficiency conditions (ppm) \\
\hline $\mathrm{Fec}$ & shoot Fe concentrations under Zn sufficiency conditions (ppm) \\
\hline Feef & $\begin{array}{l}\text { shoot Fe concentrations under } \mathrm{Zn} \text { deficiency conditions divided by shoot Fe } \\
\text { concentrations under } \mathrm{Zn} \text { sufficiency conditions }\end{array}$ \\
\hline Mnd & shoot Mn concentrations under $\mathrm{Zn}$ deficiency conditions (ppm) \\
\hline Mnc & shoot Mn concentrations under Zn sufficiency conditions (ppm) \\
\hline $\mathrm{Kd}$ & shoot $\mathrm{K}$ concentrations under $\mathrm{Zn}$ deficiency conditions $(\times 10,000 \mathrm{ppm})$ \\
\hline $\mathrm{Kc}$ & shoot $\mathrm{K}$ concentrations under $\mathrm{Zn}$ sufficiency conditions $(\times 10,000 \mathrm{ppm})$ \\
\hline $\mathrm{Cad}$ & shoot $\mathrm{Ca}$ concentrations under $\mathrm{Zn}$ deficiency conditions $(\times 10,000 \mathrm{ppm})$ \\
\hline $\mathrm{Cac}$ & shoot $\mathrm{Ca}$ concentrations under $\mathrm{Zn}$ sufficiency conditions $(\times 10,000 \mathrm{ppm})$ \\
\hline Mgd & shoot $\mathrm{Mg}$ concentrations under $\mathrm{Zn}$ deficiency conditions $(\times 10,000 \mathrm{ppm})$ \\
\hline $\mathrm{Mgc}$ & shoot $\mathrm{Mg}$ concentrations under $\mathrm{Zn}$ sufficiency conditions $(\times 10,000 \mathrm{ppm})$ \\
\hline $\mathrm{Pd}$ & shoot $\mathrm{P}$ concentrations under $\mathrm{Zn}$ deficiency conditions $(\times 10,000 \mathrm{ppm})$ \\
\hline $\mathrm{Pc}$ & shoot $\mathrm{P}$ concentrations under $\mathrm{Zn}$ sufficiency conditions $(\times 10,000 \mathrm{ppm})$ \\
\hline Cud & shoot $\mathrm{Cu}$ concentrations under $\mathrm{Zn}$ deficiency conditions (ppm) \\
\hline $\mathrm{Cuc}$ & shoot $\mathrm{Cu}$ concentrations under $\mathrm{Zn}$ sufficiency conditions (ppm) \\
\hline $\mathrm{Sd}$ & shoot $\mathrm{S}$ concentrations under $\mathrm{Zn}$ deficiency conditions $(\times 10,000 \mathrm{ppm})$ \\
\hline $\mathrm{Sc}$ & shoot $\mathrm{S}$ concentrations under $\mathrm{Zn}$ sufficiency conditions $(\times 10,000 \mathrm{ppm})$ \\
\hline Ald & shoot $\mathrm{Al}$ concentrations under $\mathrm{Zn}$ deficiency conditions (ppm) \\
\hline Alc & shoot Al concentrations under Zn sufficiency conditions (ppm) \\
\hline SBd & Shoot biomass under $\mathrm{Zn}$ deficiency conditions (mg) \\
\hline $\mathrm{SBc}$ & Shoot biomass under Zn sufficiency conditions (mg) \\
\hline TI & $\mathrm{Zn}$ deficiency tolerance index $(\%)(\mathrm{SBd} / \mathrm{SBc} * 100 \%)$ \\
\hline KRAT & {$[\mathrm{K}] /([\mathrm{Ca}]+[\mathrm{Mg}])($ Larson and Mayland 2007) } \\
\hline
\end{tabular}

This means that genetic factors controlling the homeostasis of minerals other than $\mathrm{Zn}$ are not severely affected by $\mathrm{Zn}$ availability in the growth substrate. Shoot $\mathrm{Zn}$ and Fe concentrations are positively correlated, and both are also positively correlated with shoot $\mathrm{Cu}$ concentrations. Shoot biomass (SB) is negatively correlated with the shoot $\mathrm{Zn}$ concentration, probably due to a dilution effect of $\mathrm{Zn}$ at increased growth and it is positively correlated with shoot $\mathrm{K}$ concentration, but not with $\mathrm{Fe}$ concentration. The correlations between shoot biomass and shoot mineral concentrations are similar for both growing conditions. The correlation between shoot biomass under $\mathrm{Zn}$ deficiency and $\mathrm{Zn}$ sufficiency is only moderate, suggesting a considerable genotype $\mathrm{x}$ environment interaction.

\section{QTL analyses}

The proportion of phenotypic variation in the population that is attributed to genetic variation was estimated by calculating the broad-sense heritability values for all traits (Fig. 3). Heritability values vary considerably for traits, with high heritability for $\mathrm{Fe}, \mathrm{Mn}, \mathrm{Ca}$, $\mathrm{K}, \mathrm{Mg}$ and $\mathrm{P}$ concentrations, and low heritability for $\mathrm{S}$ and $\mathrm{Cu}$ concentrations. The heritability values depend on $\mathrm{Zn}$ supply. For shoot $\mathrm{Zn}$ and Fe concentrations,

Fig. 1 Frequency distributions of the concentrations of $\mathrm{Zn}, \mathrm{Fe}$, $\mathrm{Mn}, \mathrm{Cu}, \mathrm{Al}$ (in ppm) and $\mathrm{K}, \mathrm{Ca}, \mathrm{Mg}, \mathrm{P}$ and $\mathrm{S}$ (in \%) in shoots of the Ler $\times$ Cvi RILs grown on soil under Zn deficiency (light) and sufficiency (dark) conditions. Arrows indicate the levels in the Ler (thick arrow) and Cvi (thin arrow) parental lines 


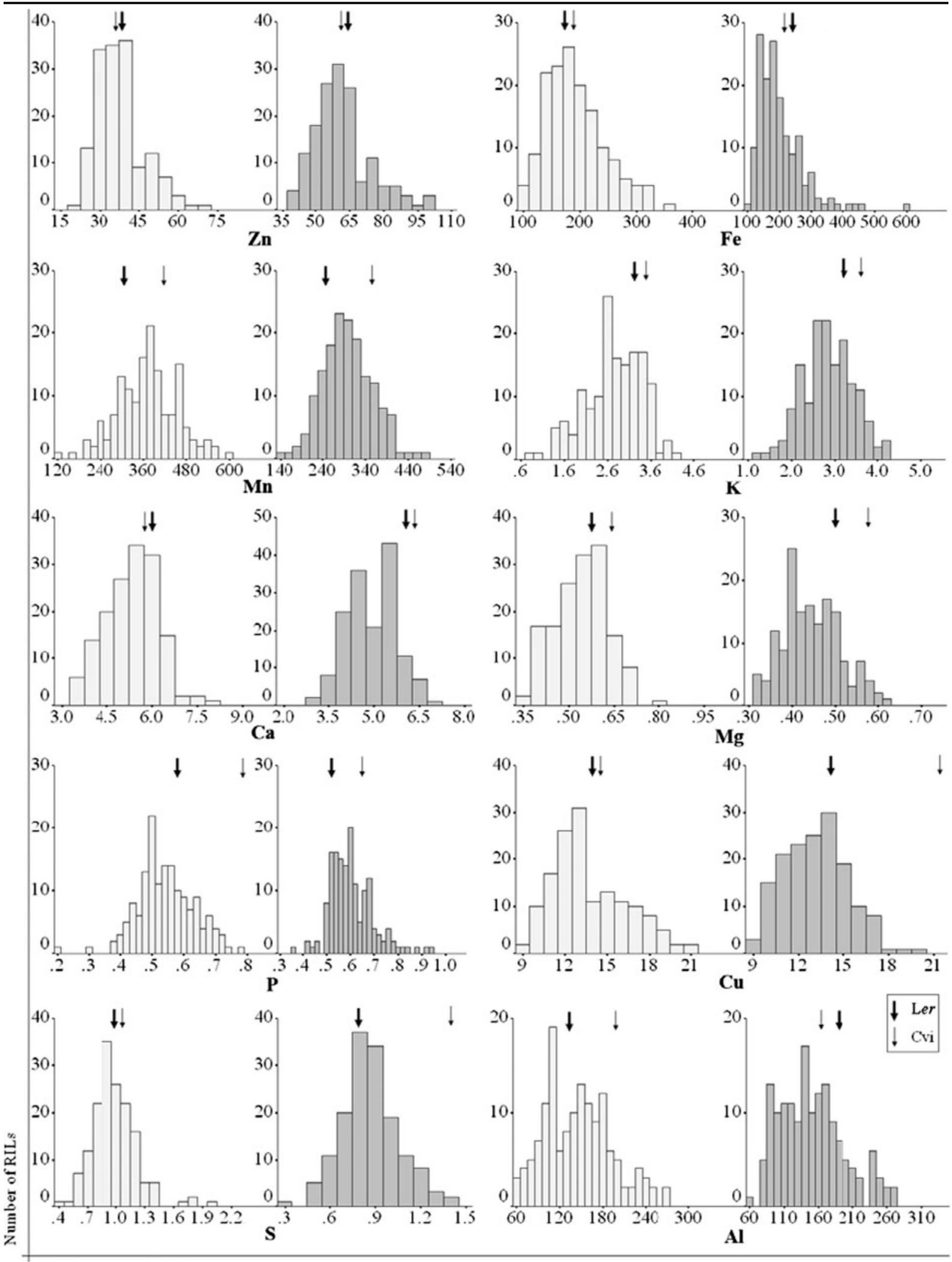

Mineral concentration in shoots 
Table 2 Fold differences for shoot mineral concentrations ( $\mathrm{Zn}$, $\mathrm{Fe}, \mathrm{Mn}, \mathrm{K}, \mathrm{Ca}, \mathrm{Mg}, \mathrm{P}, \mathrm{Cu}, \mathrm{S}$ and $\mathrm{Al}$ ), as determined by the highest mineral concentration in a RIL divided by the lowest mineral concentration in a RIL, when comparing all RILs of the Ler $\times$ Cvi population grown under $\mathrm{Zn}$ deficiency ( $\mathrm{ZnDef}$ ) or $\mathrm{Zn}$ sufficiency (ZnSuf)

\begin{tabular}{lllllllllll}
\hline & $\mathrm{Zn}$ & $\mathrm{Fe}$ & $\mathrm{Mn}$ & $\mathrm{K}$ & $\mathrm{Ca}$ & $\mathrm{Mg}$ & $\mathrm{P}$ & $\mathrm{Cu}$ & $\mathrm{S}$ & $\mathrm{Al}$ \\
\hline ZnDef & 3.1 & 3.4 & 4.8 & 4.8 & 2.3 & 2.1 & 3.5 & 2.5 & 5.2 & 4.9 \\
ZnSuf & 2.5 & 5.6 & 3.5 & 3.5 & 2.4 & 2.0 & 2.8 & 2.3 & 4.3 & 4.5 \\
\hline
\end{tabular}

heritability was higher under Zn sufficient conditions, whereas for $\mathrm{Cu}$ concentrations, it was higher under $\mathrm{Zn}$ deficient conditions. High heritability values are generally a good indication for the ability to detect QTLs controlling the traits, which is why a QTL analysis was performed of shoot mineral concentrations in response to $\mathrm{Zn}$ supply.

At least one significant QTL was identified for each mineral concentration (Fig. 4, Tables 4 and 5). Whereas 12 QTLs were found to co-locate for the same mineral when comparing the two growth conditions, there were also 26 QTLs that were only detected in one condition. In addition to QTLs with additive effects, 21 epistatic interactions between loci were identified (Table 6). Most of these interactions had relatively small phenotypic effects, and often affected the concentration of one mineral, in only one of the QTL allele pair combinations (Table 6). The total phenotypic variances explained by the QTLs represented a relatively small part of the heritability values, which means only part of the genetic variation could be assigned to QTLs while the remainder went undetected. Two hotspots for co-locating QTLs were found, one at the top of chromosome 1, around marker
AXR-1, and the other at the upper region of chromosome 5. Most of these co-located loci correspond to minerals for which shoot concentrations were found to be correlated (Table 3). The identified co-locations consisted of a mix of macro- and micro-elements.

Based on $\mathrm{K}, \mathrm{Ca}$ and $\mathrm{Mg}$ concentrations, KRAT values were determined. QTLs for KRAT values under Zn deficiency mapped to chromosome 4, while a QTL for KRAT values under $\mathrm{Zn}$ sufficiency mapped to chromosome 3. This is in accordance with the $\mathrm{K}, \mathrm{Ca}$ and $\mathrm{Mg}$ concentration differences between different growth conditions, which resulted in significantly higher KRAT values under Zn sufficiency.

\section{Discussion}

Variations in shoot mineral concentrations between genotypes can have many reasons, since many biological processes affect shoot mineral accumulation and for each process several genes are involved. Minerals need to be mobilized in the rhizosphere, where some may have to be reduced in order to be taken up by roots; minerals are then stored in root cell vacuoles or loaded into xylem for transport to shoots; in the shoot, they will need to be distributed over different tissues, and sequestered to the designated organelles (Clemens 2001; Waters and Sankaran 2011). Considering that there are large variations in available nutrients in soils, plant genotypes have developed adaptive root mechanisms to accommodate optimal chemical availability and root uptake of nutrients (Marschner 2011). Throughout the plant, various ligands are present to chelate minerals for either detoxification or mobilization, such as organic acids (citrate, malate),
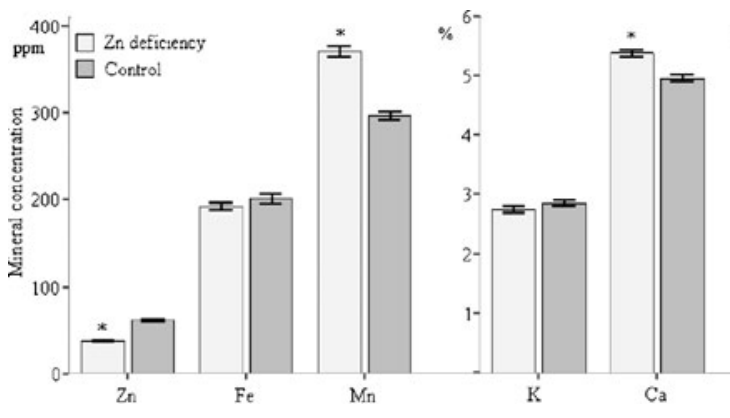

Fig. 2 Average concentrations of shoot $\mathrm{Zn}, \mathrm{Fe}, \mathrm{Mn}, \mathrm{Cu}, \mathrm{Al}$ (in ppm) and $\mathrm{K}, \mathrm{Ca}, \mathrm{Mg}, \mathrm{P}$ and $\mathrm{S}$ (in \%) $( \pm \mathrm{SE})$ of all Ler $\times \mathrm{Cvi}$ RILs grown on soil under $\mathrm{Zn}$ deficiency (light) and $\mathrm{Zn}$

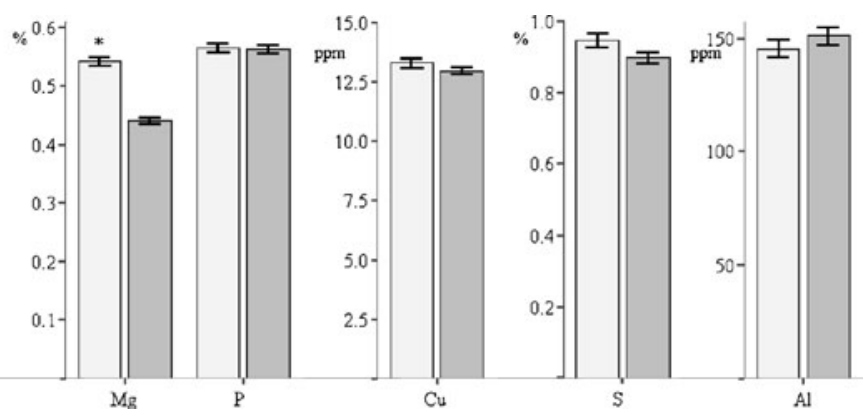

sufficiency (dark) conditions. * indicate significant differences $(P<0.05)$ between both $\mathrm{Zn}$ supply conditions 
Table 3 Correlation coefficients for mineral concentrations in shoots of the Ler $\times$ Cvi RIL population, grown at Zn deficiency or sufficiency

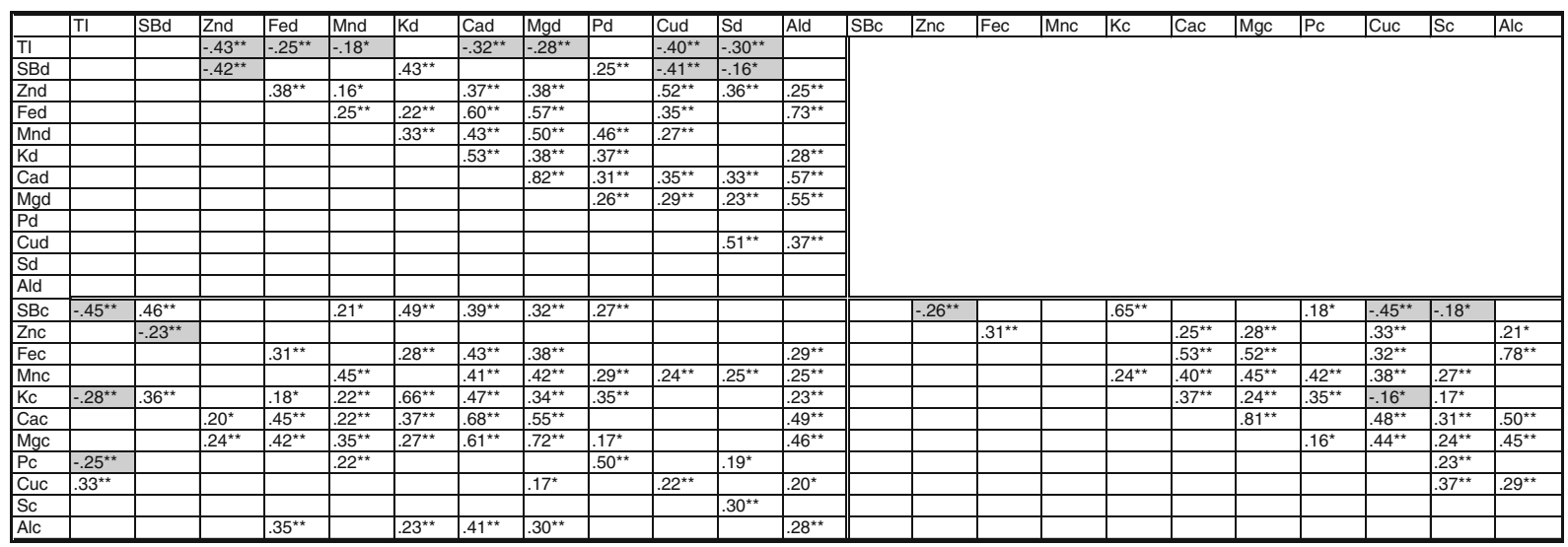

Only $r$-values that are significant at $p<0.05\left(^{*}\right)$ or $p<0.01$ levels $(* *)$ are indicated. Negative $r$-values are highlighted in grey. Note there is a strong negative correlation between $\mathrm{Zn}$ deficiency Tolerance Index and (most) mineral concentrations. See Table 1 for abbreviations of the traits

phytochelatins, histidine or nicotianamine (Haydon and Cobbett 2007). In case of $\mathrm{Zn}$ deficiency stress, plant genotypes can activate root uptake and rootto-shoot transport of $\mathrm{Zn}$ and change root morphology for better $\mathrm{Zn}$ acquisition from soil (Broadley et al. 2007; Rengel 2001). Understanding the regulation and the differences in mineral homeostasis in plants grown under different growing conditions would help to identify relevant genes involved in $\mathrm{Zn}$ acquisition from soils and $\mathrm{Zn}$ accumulation in plant tissues, for further breeding or genetic modification purposes.

For the first time we used natural $\mathrm{Zn}$ deficient soil to investigate genetic variation for mineral concentrations in Arabidopsis, which is different from previous work using this model species to investigate the genetic basis of mineral homeostasis. Because of the high $\mathrm{pH}$ and the high $\mathrm{CaCO}_{3}$ level of the soil, mineral bioavailability in general is limited and without any additional nutrient amendment, the soil we used is too poor to allow proper plant growth. We expected that differences in $\mathrm{Zn}$ bioavailability in soil would cause differences in mobilization, uptake, translocation and sequestration levels of $\mathrm{Zn}$ and other minerals, considering the shared affinities of mineral transporters and chelates, eventually leading to different mineral concentrations in various plant tissues (Clemens et al. 2002; Maser et al. 2001). We used the well-known Arabidopsis Ler $\times$ Cvi immortal RIL mapping population to identify the genetic loci controlling regulation
Fig. 3 Heritability values (in percentages) and the percentage of the total phenotypic variance explained by identified QTLs (Total Explained Variance) for mineral accumulation and shoot biomass (SB) in the Ler $\times$ Cvi RIL population grown under $\mathrm{Zn}$ deficiency ("Deficiency") or sufficiency ("Control”) conditions

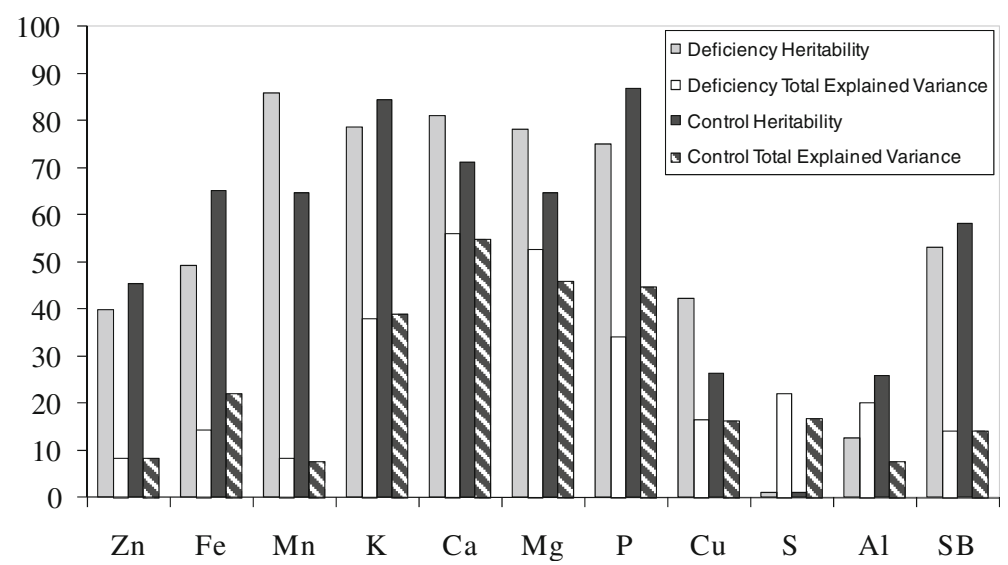




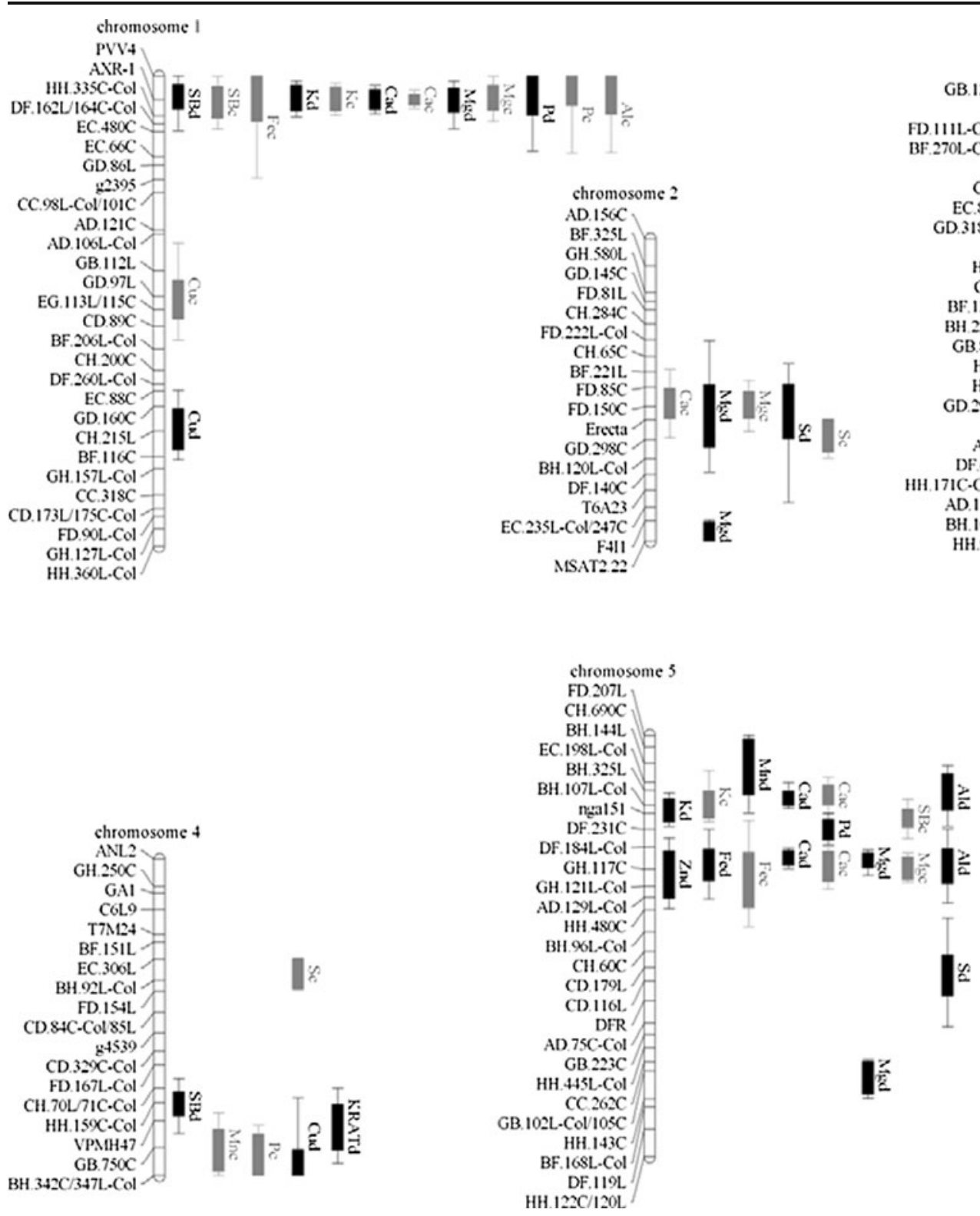

Fig. 4 Genetic map of the Ler $\times$ Cvi RIL population with identified QTLs (including 1- and 2-LOD confidence intervals; resp. thick and narrow bars) for shoot mineral concentrations of

of mineral homeostasis under Zn deficiency and compare it with the genetics of mineral homeostasis under Zn sufficiency. This population has been used before for genetic analysis of mineral accumulation (Vreugdenhil et al. 2004; Waters and Grusak 2008), and thus allows the comparison of identified QTLs over different growing conditions and tissues.

Our results shows that the genetic regulation of shoot mineral concentrations differs considerably plants grown on soil under $\mathrm{Zn}$ deficiency (dark boxes, ending on "d") and Zn sufficiency (light boxes, ending on "c") conditions. See Table 1 for abbreviations of the traits

between growth conditions. The relatively low explained variances for most of the considered traits are probably due to the presence of many genetic factors, each with relatively small allelic effects. These are difficult to detect, given the size of the population. Several of the identified QTLs were growth condition specific. Major QTLs for shoot Zn concentrations were mapped to chromosomes 3 and 5, the locus mapping to the top of chromosome 3 affecting the 
Table 4 Mineral concentration, shoot biomass and KRAT QTLs detected in the Ler $\times$ Cvi RIL population under Zn deficiency conditions as shown in Fig. 4

\begin{tabular}{llrlrrl}
\hline Trait & Chr. nr. & Position $(\mathrm{cM})$ & Closest marker & LOD & \% Expl. & Pos. allele \\
\hline Znd & 5 & 39.9 & GH.121L-Col & 2.91 & 8.4 & Cvi \\
Fed & 5 & 35.4 & GH.117C & 5.15 & 14.4 & Cvi \\
Mnd & 5 & 7.5 & BH.144L & 2.85 & 8.3 & Cvi \\
Kd & 1 & 6.4 & AXR-1 & 8.61 & 18.2 & Ler \\
Kd & 5 & 20.6 & NGA151 & 8.35 & 17.6 & Cvi \\
Cad & 1 & 6.4 & AXR-1 & 11.26 & 17.8 & Ler \\
Cad & 5 & 12.4 & EC.198L-Col & 6.74 & 13.7 & Cvi \\
Cad & 5 & 35.4 & GH.117C & 13.65 & 25.1 & Cvi \\
Mgd & 1 & 6.4 & AXR-1 & 4.06 & 6.2 & Ler \\
Mgd & 2 & 44.9 & FD.150C & 3.89 & 5.9 & Ler \\
Mgd & 2 & 80.7 & MSAT2.22 & 3.16 & 4.8 & Cvi \\
Mgd & 5 & 35.4 & GH.117C & 14.46 & 26.0 & Cvi \\
Mgd & 5 & 88.9 & GB.102L-Col/105C & 2.91 & 4.4 & Ler \\
Pd & 1 & 15.1 & EC.480C & 4.71 & 10.0 & Ler \\
Pd & 3 & 0.0 & DF.77C & 7.02 & 15.4 & Cvi \\
Pd & 5 & 24.9 & DF.231C & 3.43 & 7.1 & Cvi \\
Cud & 1 & 95.1 & CH.215L & 3.97 & 11.0 & Cvi \\
Cud & 4 & 84.0 & BH.342C/347L-Col & 2.70 & 7.3 & Cvi \\
Sd & 2 & 48.4 & Erecta & 3.71 & 9.0 & Ler \\
Sd & 3 & 73.4 & DF.65L-Col & 2.71 & 6.4 & Cvi \\
Sd & 5 & 65.0 & CD.116L & 3.02 & 7.5 & Cvi \\
Ald & 5 & 12.4 & EC.198L-Col & 4.06 & 12.2 & Cvi \\
Ald & 5 & 35.4 & GH.117C & 4.45 & 13.3 & Cvi \\
Ald & 1 & 6.4 & AXR-1 & 2.61 & 7.6 & Ler \\
SBd & 1 & 6.4 & AXR-1 & 2.43 & 6.3 & Ler \\
SBd & 4 & 64.6 & HH.159C-Col & 2.78 & 7.3 & Ler \\
KRAT & 4 & 69.4 & 3.48 & 10.2 & Ler \\
\hline & & & & & & \\
\hline
\end{tabular}

Trait explanations are provided in Table 1. Per QTL is its chromosome number (Chr. Nr.) and position in centi Morgan indicated, as well as the marker closest to the peak of the QTL, its maximum additive logarithm of odds value (LOD), the percentage of variance explained by the QTL (\% Expl.) and the parental origin of the allele contributing to an increase of the trait value (pos. allele)

shoot $\mathrm{Zn}$ concentration under sufficient supply and the locus on chromosome 5 involved in the shoot $\mathrm{Zn}$ concentration under $\mathrm{Zn}$ deficiency. As there was no obvious correlation between shoot $\mathrm{Zn}$ concentrations when comparing both growth conditions, and since the identified QTLs did not co-locate, there is specific genetic variation for genes controlling shoot $\mathrm{Zn}$ concentrations depending on $\mathrm{Zn}$ availability. Both of these loci co-locate with loci detected before in the same population for $\mathrm{Zn}$ concentration in seeds (Vreugdenhil et al. 2004; Waters and Grusak 2008) and in other populations for $\mathrm{Zn}$ concentration in seeds or rosette leaves (Ghandilyan et al. 2009a, b). It is tempting to conclude that this indicates genetic variation of the same genes, but it may also indicate different genes. Only cloning and confirmation of the cloned loci by reciprocal transformation of contrasting alleles, can verify this. The locus on chromosome 5 co-locates with QTLs for Fe, $\mathrm{Mg}$ and Ca concentrations, found for both $\mathrm{Zn}$ sufficient and deficient conditions. In the same region, QTLs were previously found for $\mathrm{Fe}$ and $\mathrm{Mg}$ concentrations in seeds (Waters and Grusak 2008). The confidence interval of the $\mathrm{Zn}$ concentration locus overlaps with those for seed Zn concentration QTLs previously found in the Ler $\times$ Cvi and Ler $\times$ An-1 populations (Ghandilyan et al. 2009b; Vreugdenhil et al. 2004), but 
Table 5 Mineral concentration, shoot biomass and KRAT QTLs detected in the Ler $\times$ Cvi RIL population under $\mathrm{Zn}$ sufficiency conditions as shown in Fig. 4

Trait explanations are provided in Table 1. Per QTL is its chromosome number (Chr. Nr.) and position in centi Morgan indicated, as well as the marker closest to the peak of the QTL, its maximum additive logarithm of odds value (LOD), the percentage of variance explained by the QTL (\% Expl.) and the parental origin of the allele contributing to an increase of the trait value (pos. allele)

\begin{tabular}{llclrrl}
\hline Trait & Chr. nr. & Position (cM) & Closest marker & LOD & $\%$ Expl. & Pos. allele \\
\hline Zns & 3 & 16.3 & BF.270L-Col/271C & 2.82 & 8.2 & Ler \\
Fes & 1 & 6.4 & AXR-1 & 2.75 & 6.5 & Ler \\
Fes & 5 & 42.9 & AD.129L-Col & 4.75 & 11.6 & Cvi \\
Mns & 4 & 76.6 & GB.750C & 2.72 & 7.6 & Cvi \\
Ks & 1 & 6.4 & AXR-1 & 9.59 & 20.8 & Ler \\
Ks & 5 & 20.6 & NGA151 & 7.81 & 16.4 & Cvi \\
Cas & 1 & 6.4 & AXR-1 & 12.87 & 20.9 & Ler \\
Cas & 2 & 44.9 & FD.150C & 2.90 & 4.1 & Ler \\
Cas & 3 & 16.3 & BF.270L-Co1/271C & 2.87 & 4.0 & Ler \\
Cas & 5 & 12.4 & EC.198L-Col & 4.76 & 8.1 & Cvi \\
Cas & 5 & 35.4 & GH.117C & 7.93 & 12.8 & Cvi \\
Mgs & 1 & 6.4 & AXR-1 & 3.98 & 6.8 & Ler \\
Mgs & 2 & 44.9 & FD.150C & 3.92 & 6.7 & Ler \\
Mgs & 5 & 35.4 & GH.117C & 13.24 & 26.1 & Cvi \\
Ps & 1 & 0 & PVV4 & 2.67 & 4.6 & Ler \\
Ps & 3 & 0 & DF.77C & 15.78 & 33.3 & Cvi \\
Ps & 3 & 79.3 & AD.112L-Col & 4.40 & 7.8 & Cvi \\
Ps & 4 & 84,0 & BH.342C/347L-Col & 4.10 & 7.2 & Cvi \\
Cus & 1 & 62.5 & EG.113L/115C & 2.41 & 6.1 & Cvi \\
Cus & 3 & 16.3 & BF.270L-Col/271C & 3.90 & 10.2 & Ler \\
Ss & 2 & 53.6 & GD.298C & 3.78 & 10.2 & Ler \\
Ss & 4 & 32.2 & BH.92L-Col & 2.80 & 7.4 & Cvi \\
SBs & 1 & 6.4 & AXR-1 & 3.19 & 7.9 & Ler \\
SBs & 5 & 20.6 & NGA151 & 4.88 & 12.4 & Cvi \\
KRAT & 3 & 16.3 & BF.270L-Col/271C & 2.86 & 8.5 & Cvi \\
\hline & & & & & \\
\hline
\end{tabular}

since the QTL peaks are not mapping in close vicinity, this QTL appears to be different from the one detected previously. Overlap of this QTL with the Fe concentration QTL can indicate genetic variation for one gene involved in both $\mathrm{Zn}$ and $\mathrm{Fe}$ homeostasis, which is not unexpected as they share part of their molecular regulation (Colangelo and Guerinot 2004; van de Mortel et al. 2006). The locus on chromosome 3 appears to be more specific to $\mathrm{Zn}$. It maps to a region close to the FRD3 gene (At3g08040; www.arabidopsis.org), but when fine-mapping the locus for $\mathrm{Zn}$ concentration in seeds (Vreugdenhil et al. 2004), FRD3 was not mapped to the fine-mapping interval $(\mathrm{Du}$ and Aarts, unpublished results).

Although the confidence intervals for the identified QTLs are large, there are several candidate genes in the intervals, that could account for the QTLs, e.g. FER2 (ferritin), MTP5 (a vacuolar cation importer), ZIP1 (a cell membrane $\mathrm{Zn}$ transporter), CAX2, CAX9 (low-affinity calcium transporters), $\mathrm{CH} X 3, \mathrm{CH} X$, CHX18, CHX19, CHX24 (cation $/ \mathrm{H}^{+}$exchangers), CNGC19, CNGC20 (ion channels), MGT3 (a magnesium transporter) and FRO2 (ferric reductase), but equally many, including the well-known HMA4 involved in $\mathrm{Zn}$ root to shoot translocation, that are not within the confidence intervals. However, without further fine-mapping it is not possible to indicate any of these as more or less likely candidates.

In general, different traits can be genetically correlated due to pleiotropy (one gene affecting different traits) or due to close linkage of different genes with different functions (Jiang and Zeng 1995). Since several correlations were found when comparing concentrations of different minerals, the co-locations of QTLs for these concentrations suggest some sharing of mechanisms controlling homeostasis. Not all QTLs identified in the present study co-located with the QTLs identified previously for Arabidopsis seeds in 
Table 6 Epistatic marker interactions $(P<0.001)$ for examined traits (see Table 1 for explanation of the abbreviations) in the Ler $\times$ Cvi RIL population grown under Zn sufficient and deficient conditions

\begin{tabular}{|c|c|c|c|c|c|c|}
\hline \multirow[t]{2}{*}{ Trait } & \multirow[t]{2}{*}{ Epistatic marker interaction } & \multirow[t]{2}{*}{ LLR $^{b}$} & \multicolumn{4}{|c|}{ Trait means of each marker pair } \\
\hline & & & LL & $\mathrm{LC}$ & CL & $\mathrm{CC}$ \\
\hline Znc & $\mathrm{g} 2395 \times \mathrm{GA} 1$ & 7.9 & $58^{\mathrm{a}}$ & $68^{\mathrm{b}}$ & $62^{\mathrm{ab}}$ & $58^{\mathrm{a}}$ \\
\hline Znc & BF. $221 \mathrm{~L} \times \mathrm{T} 6 \mathrm{~A} 23$ & 6.4 & $63^{\mathrm{a}}$ & $60^{\mathrm{ab}}$ & $54^{\mathrm{b}}$ & $65^{\mathrm{a}}$ \\
\hline $\mathrm{Znc}$ & FD.111L-Col/136C $\times$ BH.225C-Col & 7.1 & $61^{\mathrm{a}}$ & $66^{\mathrm{a}}$ & $63^{\mathrm{a}}$ & $53^{\mathrm{b}}$ \\
\hline Znc & BF.270L-Col/271C $\times$ BH.144L & 6.1 & $61^{\mathrm{a}}$ & $70^{b}$ & $59^{\mathrm{a}}$ & $55^{\text {a }}$ \\
\hline Znd & GD.298C $\times$ HH.480C & 6.9 & $40^{\mathrm{a}}$ & $38^{\mathrm{ab}}$ & $34^{b}$ & $41^{\mathrm{a}}$ \\
\hline Znd & GB.80C-Col $\times$ BH.107L-Col & 7.7 & $36^{\mathrm{a}}$ & $41^{\mathrm{ab}}$ & $41^{\mathrm{b}}$ & $36^{\mathrm{a}}$ \\
\hline Znef & DF.65L-Col × BH.96L-Col & 7.1 & $0.58^{\mathrm{a}}$ & $0.68^{\mathrm{ab}}$ & $0.75^{b}$ & $0.6^{\mathrm{a}}$ \\
\hline Znef & DF.184L-Col × CD.179L & 7.2 & $0.59^{\mathrm{a}}$ & $0.69^{\mathrm{ab}}$ & $0.82^{b}$ & $0.6^{\mathrm{a}}$ \\
\hline $\mathrm{Fec}$ & EC $.480 \mathrm{C} \times$ GB. $80 \mathrm{C}-\mathrm{Col}$ & 6.1 & $197^{\mathrm{a}}$ & $253^{\mathrm{b}}$ & $197^{\mathrm{a}}$ & $174^{\mathrm{a}}$ \\
\hline $\mathrm{Fec}$ & CC.98L-Col/101C × GD.97L & 7.4 & $227^{\mathrm{a}}$ & $195^{\mathrm{ab}}$ & $167^{b}$ & $199^{\mathrm{ab}}$ \\
\hline $\mathrm{Fec}$ & FD. 167L-Col $\times$ FD.207L & 6.5 & $185^{\mathrm{a}}$ & $245^{b}$ & $193^{\mathrm{a}}$ & $179^{\mathrm{a}}$ \\
\hline $\mathrm{Fec}$ & AD.129L-Col $\times$ nga151 & 11.8 & $184^{\mathrm{a}}$ & $198^{\mathrm{a}}$ & $165^{\mathrm{a}}$ & $256^{\mathrm{b}}$ \\
\hline $\mathrm{Fec}$ & BH.96L-Col × GD.97L & 5.8 & $181^{\mathrm{a}}$ & $251^{\mathrm{b}}$ & $198^{\mathrm{a}}$ & $198^{\mathrm{a}}$ \\
\hline Fed & EC. $66 \mathrm{C} \times$ BF. $168 \mathrm{~L}-\mathrm{Col}$ & 6.6 & $207^{\mathrm{a}}$ & $188^{\mathrm{ab}}$ & $175^{\mathrm{b}}$ & $211^{\mathrm{a}}$ \\
\hline Fed & EC.198L-Col $\times$ CD.329C-Col & 10.4 & $176^{\mathrm{a}}$ & $248^{b}$ & $185^{\mathrm{a}}$ & $184^{\mathrm{a}}$ \\
\hline Feef & CC.98L-Col/101C $\times$ GD.97L & 10.9 & $0.9^{\mathrm{a}}$ & $1.18^{\mathrm{b}}$ & $1.21^{\mathrm{b}}$ & $1.01^{\mathrm{ab}}$ \\
\hline $\mathrm{SBc}$ & BH.107L-Col $\times$ GB.80C-Col & 5.6 & $5.9^{\mathrm{a}}$ & $6.2^{\mathrm{a}}$ & $5.6^{\mathrm{a}}$ & $8.3^{\mathrm{b}}$ \\
\hline $\mathrm{SBc}$ & PVV4 × CH.215L & 7.7 & $6.9^{\mathrm{a}}$ & $6.4^{\mathrm{ab}}$ & $5.2^{b}$ & $6.7^{\mathrm{a}}$ \\
\hline SBd & PVV4 $\times$ CH.215L & 6.9 & $6.2^{\mathrm{a}}$ & $5.1^{\mathrm{ab}}$ & $4.8^{\mathrm{b}}$ & $5.9^{\mathrm{a}}$ \\
\hline TI & BH.120L-Col $\times$ FD.111L-Col/136C & 12.6 & $83^{\mathrm{ab}}$ & $96^{\mathrm{bc}}$ & $108^{c}$ & $73^{\mathrm{a}}$ \\
\hline $\mathrm{TI}$ & HH.410C $\times$ CD.179L & 6.8 & $91^{\mathrm{a}}$ & $97^{\mathrm{a}}$ & $96^{\mathrm{a}}$ & $65^{\mathrm{b}}$ \\
\hline
\end{tabular}

Different letters following the trait means indicate significant differences among four combinations of each pair of epistatically interacting loci $(P<0.05)$, with $\mathrm{L}$ indicating the Ler allele and $\mathrm{C}$ the $\mathrm{Cvi}$ allele. For each combination, the log likelihood ratio values are given (LLR)

the same population (Vreugdenhil et al. 2004; Waters and Grusak 2008). The reason for this apparent discrepancy could be the difference in growing conditions (nutrient amended $\mathrm{Zn}$ deficient calcareous soil vs. peat-based potting soil) as well as the fact that regulation of mineral homeostasis depends on organ type as well (Ghandilyan et al. 2009b).

We found a negative correlation between shoot $\mathrm{Zn}$ concentrations and shoot biomass on $\mathrm{Zn}$ deficient and sufficient conditions. Previously, we also found a negative correlation between organ dry weight and $\mathrm{Zn}$ concentration in other populations and growing conditions (Ghandilyan et al. 2009b). The same phenomenon was observed in other species (Morgounov et al. 2007; Shi et al. 2008), and is probably caused by a dilution effect. When plants grow, they will have to spread the accumulated minerals over a larger volume, thus decreasing the mineral concentration. The same we found previously for other minerals, such as in the Ler $\times$ An-1 population, which was grown in water deficit and optimal conditions (Ghandilyan et al. 2009a), in which clusters of mineral concentration QTLs often cosegregated with dry weight QTLs. One obvious region for such co-segregation of QTLs is the top of chromosome 1, indicating QTLs for shoot biomass and for several mineral concentrations (Fig. 4). This region contains the CRY2 gene, encoding for the CRYPTOCHROME 2 blue light receptor (El-Assal et al. 2001). When comparing wild type and mutant plants, we found that this gene affects seed mineral concentrations via variation in yield or yield-associated parameters and flowering time (Ghandilyan and Aarts, unpublished results). Our observation that two major QTLs, for shoot Zn concentrations in both growing 
conditions, did not co-locate with the identified QTLs for shoot biomass, is assuring evidence that there are QTLs additional to growth QTLs that control shoot $\mathrm{Zn}$ accumulation.

The concentrations of other minerals was also affected by $\mathrm{Zn}$ deficiency, but these concentrations were less dependent on $\mathrm{Zn}$ availability. That is probably also the reason that many QTLs were found under both $\mathrm{Zn}$ sufficient and deficient conditions. One example is the QTL for shoot P concentration mapped to the top of chromosome 3. Previously, QTLs for phosphorus and phytate concentrations in different plant organs were detected at this position in several populations (Bentsink et al. 2003; Ghandilyan et al. 2009a, b; Vreugdenhil et al. 2004; Waters and Grusak 2008).

Overall, this analysis identified several shoot mineral concentration QTLs in Arabidopsis, adding to our knowledge on genetic variation for mineral homeostasis. Although some QTLs were found to be specific for one of the two $\mathrm{Zn}$ supply conditions, many were not, meaning that an alteration in $\mathrm{Zn}$ supply does not necessarily have a considerable effect on the homeostasis of other mineral nutrients.

Acknowledgments We gratefully acknowledge the help of Corrie Hanhart in preparing the seeds of the RIL population and the support of COST Actions 859 (Phytotechnologies to promotesustainable land use and improve food safety) and FA0905 (Mineral improved crop production for healthy food and feed) to support this work with grants to AG and UBK. We thank Maarten Koornneef for critically reading this manuscript and for providing valuable comments for its improvement.

Open Access This article is distributed under the terms of the Creative Commons Attribution License which permits any use, distribution, and reproduction in any medium, provided the original author(s) and the source are credited.

\section{References}

Aciksoz S, Yazici M, Ozturk L, Cakmak I (2011) Biofortification of wheat with iron through soil and foliar application of nitrogen and iron fertilizers. Plant Soil 349:215-225

Alloway B (2008) Zinc in soils and crop nutrition. In IZA Publications

Alonso-Blanco C, Peeters AJ, Koornneef M, Lister C, Dean C, van den Bosch N, Pot J, Kuiper MT (1998) Development of an AFLP based linkage map of Ler, Col and Cvi Arabidopsis thaliana ecotypes and construction of a Ler/Cvi recombinant inbred line population. Plant J 14:259-271
Alonso-Blanco C, Aarts MGM, Bentsink L, Keurentjes JJB, Reymond M, Vreugdenhil D, Koornneef M (2009) What has natural variation taught us about plant development, physiology, and adaptation? Plant Cell 21:1877-1896

Bentsink L, Yuan K, Koornneef M, Vreugdenhil D (2003) The genetics of phytate and phosphate accumulation in seeds and leaves of Arabidopsis thaliana, using natural variation. Theor Appl Genet 106:1234-1243

Bouis HE (2002) Plant breeding: a new tool for fighting micronutrient malnutrition. J Nutr 132:491S-494

Broadley MR, White PJ, Hammond JP, Zelko I, Lux A (2007) Zinc in plants. New Phytol 173:677-702

Cakmak I (2000) Possible roles of zinc in protecting plant cells from damage by reactive oxygen species. New Phytol 146:185-205

Cakmak I (2008) Enrichment of cereal grains with zinc: agronomic or genetic biofortification? Plant Soil 302:1-17

Cakmak I, Yilmaz A, Kalayci M, Ekiz H, Torun B, Erenoglu B, Braun HJ (1996) Zinc deficiency as a critical problem in wheat production in Central Anatolia. Plant Soil 180:165-172

Cakmak I, KalaycI M, Ekiz H, Braun HJ, KilInç Y, Yilmaz A (1999a) Zinc deficiency as a practical problem in plant and human nutrition in Turkey: a NATO-science for stability project. Field Crop Res 60:175-188

Cakmak I, Tolay I, Ozdemir A, Ozkan H, Ozturk L, Kling CI (1999b) Differences in zinc efficiency among and within diploid, tetraploid and hexaploid wheats. Ann Bot 84:163171

Chase K, Adler FR, Lark KG (1997) EPISTAT: a computer program for identifying and testing interactions between pairs of quantitative trait loci. Theor Appl Genet 94:724730

Clemens S (2001) Molecular mechanisms of plant metal tolerance and homeostasis. Planta 212:475-486

Clemens S, Palmgren MG, Krämer U (2002) A long way ahead: understanding and engineering plant metal accumulation. Trends Plant Sci 7:309-315

Colangelo EP, Guerinot ML (2004) The essential basic helixloop-helix protein FIT1 is required for the iron deficiency response. Plant Cell 16:3400-3412

El-Assal SE-D, Alonso-Blanco C, Peeters AJM, Raz V, Koornneef M (2001) A QTL for flowering time in Arabidopsis reveals a novel allele of $C R Y 2$. Nat Genet 29:435-440

Genc Y, Verbyla AP, Torun AA, Cakmak I, Willsmore K, Wallwork H, McDonald GK (2009) Quantitative trait loci analysis of zinc efficiency and grain zinc concentration in wheat using whole genome average interval mapping. Plant Soil 314:49-66

Ghandilyan A, Vreugdenhil D, Aarts MGM (2006) Progress in the genetic understanding of plant iron and zinc nutrition. Physiol Plant 126:407-417

Ghandilyan A, Barboza L, Tisné S, Granier C, Reymond M, Koornneef M, Schat H, Aarts MGM (2009a) Genetic analysis identifies quantitative trait loci controlling rosette mineral concentrations in Arabidopsis thaliana under drought. New Phytol 184:180-192

Ghandilyan A, Ilk N, Hanhart C, Mbengue M, Barboza L, Schat H, Koornneef M, El-Lithy M, Vreugdenhil D, Reymond M, Aarts MGM (2009b) A strong effect of growth medium and organ type on the identification of QTLs for phytate and mineral concentrations in three 
Arabidopsis thaliana RIL populations. J Exp Bot 60:1409-1425

Graham RD (1984) Breeding for nutritional characteristics in cereals. Advances in Plant Nutrition 1:57-102

Haydon MJ, Cobbett CS (2007) Transporters of ligands for essential metal ions in plants. New Phytol 174:499-506

Jiang C, Zeng ZB (1995) Multiple trait analysis of genetic mapping for quantitative trait loci. Genetics 140:1111-1127

Larson S, Mayland H (2007) Comparative mapping of fiber, protein, and mineral content QTLs in two interspecific Leymus wildrye full-sib families. Molecular Breeding 20:331-347

Marschner P (2011) Mineral nutrition of higher plants. Academic Press Inc. pp 672

Maser P, Thomine S, Schroeder JI, Ward JM, Hirschi K, Sze H, Talke IN, Amtmann A, Maathuis FJ, Sanders D, Harper JF, Tchieu J, Gribskov M, Persans MW, Salt DE, Kim SA, Guerinot ML (2001) Phylogenetic relationships within cation transporter families of Arabidopsis. Plant Physiol 126:1646-1667

Morgounov A, Gómez-Becerra HF, Abugalieva A, Dzhunusova M, Yessimbekova M, Muminjanov H, Zelenskiy Y, Ozturk L, Cakmak I (2007) Iron and zinc grain density in common wheat grown in Central Asia. Euphytica 155:193-203

Rengel Z (2001) Genotypic differences in micronutrient use efficiency in crops. Communications in Soil Science and Plant Analysis 32:1163-1186

Rengel Z, Batten GD, Crowley DE (1999) Agronomic approaches for improving the micronutrient density in edible portions of field crops. Field Crop Res 60:27-40
Shi R, Li H, Tong Y, Jing R, Zhang F, Zou C (2008) Identification of quantitative trait locus of zinc and phosphorus density in wheat (Triticum aestivum L.) grain. Plant Soil 306:95-104

Sillanpaeae M (1982) Micronutrients and the nutrient status of soils: a global study. FAO Soils Bulletin, no.48, Rome, Italy

van de Mortel JE, Almar Villanueva L, Schat H, Kwekkeboom J, Coughlan S, Moerland PD, Loren V, van Themaat E, Koornneef M, Aarts MGM (2006) Large expression differences in genes for iron and zinc homeostasis, stress response, and lignin biosynthesis distinguish roots of Arabidopsis thaliana and the related metal hyperaccumulator Thlaspi caerulescens. Plant Physiol 142:1127-1147

Vreugdenhil D, Aarts MGM, Koornneef M, Nelissen H, Ernst WHO (2004) Natural variation and QTL analysis for cationic mineral content in seeds of Arabidopsis thaliana. Plant Cell Environ 27:828-839

Waters BM, Grusak MA (2008) Quantitative trait locus mapping for seed mineral concentrations in two Arabidopsis thaliana recombinant inbred populations. New Phytol 179:1033-1047

Waters BM, Sankaran RP (2011) Moving micronutrients from the soil to the seeds: Genes and physiological processes from a biofortification perspective. Plant Sci 180:562-574

Wissuwa M, Ismail AM, Yanagihara S (2006) Effects of zinc deficiency on rice growth and genetic factors contributing to tolerance. Plant Physiol 142:731-741

Wu J, Schat H, Sun R, Koornneef M, Wang X, Aarts MGM (2007) Characterization of natural variation for zinc, iron and manganese accumulation and zinc exposure response in Brassica rapa L. Plant Soil 291:167-180 